\title{
Editorial: Coping with Covid
}

\author{
Philip Machanick iD sacj.editor@gmail.com
}

Department of Computer Science, Rhodes University, South Africa

\section{Introduction}

I am pleased to report that $S A C J$ has been able to publish on schedule in July 2020 despite the Covid-19 (SARS-CoV-2) pandemic. South Africa, like many other countries, has been severely impacted by prevention measures.

South African academics have had to try to work out how to do remote delivery of courses with inadequate resources. At my own university, there has been a major upsurge in students supported by the National Student Financial Aid Scheme (NSFAS). These students are from poor families, many with no prior exposure to higher education, and from all over the country as well as further afield. As one of the country's smallest universities, we have also become one of the most diverse.

I hope we do not lose significant numbers of students to the additional academic stresses.

In this editorial I look at how academia can respond to a crisis like this. I also outline an upcoming special issue and some transitions including a sad event arising from the pandemic, a warning to all of us.

\section{Our Role in A Major Crisis}

Academics, particularly in the disciplines represented in $S A C J$, can play many roles in a crisis such as the Covid-19 pandemic.

The role of communication is significant. We conduct all of our meetings remotely using technologies such as Zoom. While we as academics do not create these technologies we can play a major role in helping community and our fellow less technical academics to use them.

Understanding how technology can be used to combat the virus is also a role some of us can play. I have editorialized about the necessity for open science in South Africa's efforts to contain the virus (Machanick, 2020) and have attempted to understand modelling methods used by epidemiologists who have too much on their hands to communicate as much as they would probably like.

\footnotetext{
Machanick, P. (2020). Editorial: Coping with Covid [Editorial]. South African Computer Journal 32(1), vii-ix. 10. 18489/sacj.v32i 1.858

Copyright (C) the author(s); published under a Creative Commons NonCommercial 4.0 License (CC BY-NC 4.0). $S A C J$ is a publication of the South African Institute of Computer Scientists and Information Technologists. ISSN 1015-7999 (print) ISSN 2313-7835 (online).
} 


\section{FAIR 2019}

We are working on a special issue of extended papers from the inaugural Artificial Intelligence research conference, Forum on AI Research (FAIR), held in Cape Town, South Africa over 3-6 December 2019.

Our rule for extended papers is that, while we relax originality requirements in that up to $70 \%$ of the paper can be the same as the original, the new material must be substantial and the paper must meet journal standards for review.

We do not have an open call for extended papers as demand exceeds our capacity to run special issues; we are pleased to have submissions from a strong event like this.

\section{Transitions}

Machdel Matthee leaves us as an Information Systems editor and we welcome Hanlie Smuts who takes over her slot. We thank Machdel for her contribution. Another of our IS editors, Caroline Khene, was due to move mid-April 2020 to De Montfort University in Leicester, UK while continuing in her role. Her move has been delayed by Covid-19, though her affiliation has changed.

I am also sad to report the death of Ken MacGregor, who contracted Covid-19; you can read an obituary from his long-term colleague Sonia Berman in this issue (Berman, 2020).

\section{In this issue}

In this issue, we have five research papers:

- Almomanya et al.: “An OpenCL-Based Parallel Acceleration of a Sobel Edge Detection Algorithm Using Intel FPGA Technology"

- Cilliers and Chinyamurindi: "Perceptions of Cyber Bullying at Primary and Secondary School Level amongst Student Teachers in the Eastern Cape Province of South Africa"

- Khoza and Marnewick: "Waterfall and Agile Information System Project Success Rates A South African Perspective"

- Mongwe and Malan: "A Survey of Automated Financial Statement Fraud Detection with Relevance to the South African Context"

- Zenda et al.: 'Protection of Personal Information: An Experiment Involving Data Value Chains and the use of Personal Information for Marketing Purposes in South Africa" 


\section{Future}

We are starting to transition to using Overleaf as it makes collaborative editing of LaTeX easier. There will be further updates on this once we gain experience with using it in final production. I thank production editor James Dibley for paying the cost of a collaborative license for Overleaf.

\section{References}

Berman, S. (2020). Obituary: Ken MacGregor [Communication]. South African Computer Journal, 32(1). 10.18489/sacj.v32i1.863

Machanick, P. (2020). Covid-19: Liberate the evidence. Mail \& Guardian, 36, 22-22. https: //mg.co.za/coronavirus-essentials/2020-06-09-covid-19-free-the-evidence/ 